\title{
O COSMOPOLITISMO E A PROTEÇÃO INTERNACIONAL DOS DIREITOS HUMANOS SOB UM ENFOQUE DA UNIÃo EUROPEIA E DA NECESSIDADE DE DIÁlOGO COM OS CIDADÃOS
}

The cosmopolitanism and the international protection of human rights under an approach to the European Union and the need for dialogue with citizens

\section{Letícia Bodanese Rodegheri}

Mestranda em Direito pela Universidade Federal de Santa Maria - Linha de Pesquisa Direitos da Sociedade em Rede. Graduada em Direito pela Universidade Federal de Santa Maria. Integrante do Núcleo de Direito Informacional (NUDI). E-mail: leticiabrodegheri@gmail.com.

RECEBIDO EM: 17.05.2014

APROVADO EM: 01.08.2014

\section{Resumo}

A busca pela paz universal remonta há séculos e ainda não foi alcançada pelo homem. Emergem conflitos bélicos, econômicos e, com o desenvolvimento das tecnologias, sempre há inovações e o acirramento das disputas por poder. Em que pese à existência deste cenário, não se pode perder de vista a proteção aos direitos humanos. Mostra-se necessária a construção de uma comunidade cosmopolita, baseada na solidariedade, cooperação e colaboração entre os mais variados atores: Estados, ordens transnacionais, organizações não governamentais e, também, os cidadãos. O presente artigo, utilizando-se do método de abordagem dedutivo, objetiva encontrar formas de solução dos problemas globais, especialmente no que se refere à possibilidade de participação popular. Realizou-se análise sistemática, direta e não participativa na ferramenta "A sua voz na Europa", utilizada pela União Europeia com a finalidade de atrair o diálogo com os indivíduos. Conclui-se que o diálogo transconstitucional entre Estados e organizações internacionais tem-se revelado importante e útil para a solução de litígios envolvendo questões que transcendem as fronteiras dos Estados. No entanto, quanto à participação popular, o mecanismo encontrado ainda se mostra incipiente e denota mais um espaço de publicização das informações do que, efetivamente, de construção de ideias e debates entre cidadãos. 
Palavras-chave: Cosmopolitismo. Paz universal. União Europeia. Diálogo. CiDADÃO.

\begin{abstract}
The search for universal peace dates back centuries and has not yet been reached by man. Emerge war, and economic conflicts that, with the development of technology, there are always innovations and intensification of disputes for power. Despite the existence of this scenario, it cannot lose sight of the human rights protection. It is necessary to construct a cosmopolitan community based on solidarity, cooperation and collaboration among the various actors: states, transnational orders, non-governmental organizations and also citizens. This paper, using the deductive method of approach aims to find ways of solving global problems, especially with regard to the possibility of popular participation. It was realized a systematic, direct and non-participatory analysis in the online tool "Your Voice in Europe", used by the European Union in order to attract the dialogue with individuals. The conclusion is that the transconstitucional dialogue between States and international organizations has proved important and useful for resolving disputes involving issues that transcend national borders. However, the popular participation in the mechanism found is still incipient and denotes more space for the information publicity than actually the ideas construction and debates among citizens.
\end{abstract}

Keywords: Cosmopolitanism. Universal peace. European Union. Dialogue. CitiZEN.

SUMARIO: Introdução. 1. Os desafios para a construção do cosmopolitismo: a globalização e suas implicações nos aspectos econômico, político e de proteção aos direitos humanos. 1.1. As relações inter-estatais e os desafios para o cosmopolistimo. 1.2. Proteção aos direitos humanos e a importância da "conversação" transconstitucional. 2. Os atores internacionais e as questões que transpõem barreiras temporais e territorias: a necessidade de diálogo. 2.1. O sistema da União Europeia e a margem de apreciação dos estados. 2.2. Possibilidades e desafios para a implementação de um diálogo entre estados, organizações internacionais e cidadãos. Conclusão. Referências. 


\section{INTRODUÇão}

O fenômeno da globalização implica aumento de transações econômicas entre os Estados e, também, a alteração da titularidade do domínio sobre tais relações. Se há anos atrás se afirmava com convicção a soberania e supremacia dos Estado-nação, atualmente já não se tem tanta certeza e autonomia, porque estes vêm perdendo a centralidade e titularidade de aspectos econômicos, financeiros, de imigração, entre outros. Há a emergência de fatores, ordens, organizações e fluxos autônomos que também detêm ingerência sobre o cenário mundial.

Esta multiplicação de atores internacionais e alteração na sistemática até então consolidada - de soberania dos Estados -, acarreta, dentre outros fatores, a emergência de conflitos entre as mais variadas ordens e formatos, sendo necessário entabular relações com tais organismos. Nestas relações, em que pese o aumento da capacidade tecnológica e, consequentemente, das disputas por poder político, é cada vez mais imperioso a proteção aos direitos humanos.

Esta proteção não deve ocorrer apenas através dos tratados internacionais, como também é imprescindível a interlocução entre Cortes, Parlamentos e os próprios cidadãos, para que se possibilite a coexistência de diversos e múltiplos níveis de poder. Diante desta realidade que se revela cada vez mais globalizada e interconectada, sob a perspectiva de proteção aos direitos humanos, como enfrentar os problemas político-jurídicos que envolvem questões que transpõem as fronteiras dos Estados, flexibilizando marcos temporais e territoriais? Há possibilidade de diálogo e de manifestação popular neste sentido?

Com a finalidade de responder a tais questionamentos, o presente artigo, utilizando-se do método de abordagem dedutivo, objetiva tratar de mecanismos e formas de solução de conflitos em que se prima pela proteção aos direitos humanos. Partiu-se, portanto, da necessidade de construção de solidariedade, cooperação e colaboração entre os indivíduos para, em um segundo momento, verificar a possibilidade de diálogo ou de conversação entre Estados, organizações internacionais, ordens normativas transnacionais (como a lex mercatoria, sportiva e digitalis), bem como com a participação popular. Para tanto, realizou-se uma análise sistemática, direta e não participativa na ferramenta online "A sua voz na Europa" - constante no site da União Europeia -, durante o mês de janeiro de 2014, com o intuito de verificar se há interatividade entre os cidadãos e entre estes e a União Europeia, para que se efetive este diálogo de múltiplos níveis.

A escolha recaiu sobre a União Europeia pelo alto grau de desenvolvimento e de organização da união supraestatal que conta, inclusive, com outras formas de compartilhamento e de diálogo entre a União e os Estados-Membros, a exemplo da margem de apreciação dos Estados. Trata-se de organização subsidiária e complementar à atuação dos Estados-Membros e, portanto, de fundamental importância a sua averiguação, especialmente quando se objetiva a coexistência de diversos e 
múltiplos níveis de poder.

$\mathrm{O}$ artigo foi dividido em dois tópicos centrais. Na primeira parte abordouse a dualidade existente entre a globalização e a proteção aos direitos humanos, demonstrando implicações econômicas e políticas desta dicotomia e, ainda, a possibilidade de instituição de uma república mundial federal subsidiária e complementar e a necessidade de conversação transconstitucional entre Estados, organizações não governamentais e ordens normativas transnacionais. Na segunda parte o foco de análise centrou-se na União Europeia ao demonstrar a atuação do Tribunal Europeu de Direitos Humanos e o mecanismo da margem de apreciação dos Estados - destaque para a liberdade religiosa. Efetuou-se, ainda, análise do mecanismo online "A sua voz na Europa", para verificar a possibilidade de participação popular - primordialmente através da Internet - e sua influência na tomada de decisão em questões relacionadas à União Europeia.

\section{Os desafios PARA A CONSTRUÇÃo do COSMOPOLITISMO: A GLOBALIZAÇÃo E SUAS IMPLICAÇÕES NOS ASPECTOS ECONÔMICO, POLÍTICO E DE PROTEÇÃO AOS DIREITOS HUMANOS}

Globalização, mundialização e humanização. Cotidianamente, tais palavras têm sido empregadas como sinônimas, a fim de tratar deste fenômeno global que influencia todos os Estados, relativizando a soberania dos mesmos e trazendo à tona questões nos mais variados setores - economia, política e direito, por exemplo. Porém, ao se colocar no foco central a proteção aos direitos humanos, cabe fazer uma distinção entre os termos.

De acordo com Mireille Delmas-Marty há diferenças entre os termos, porque "[...] globalização para a economia e universalização para os direitos humanos, guardando assim o termo mundialização para uma neutralidade que ele jamais perderá, caso não se resigne rapidamente ao primado da economia sobre os direitos do homem" (DELMAS-MARTY, 2003, p. 08).

Isso demonstra a existência de certa dualidade ${ }^{79}$ que permeia não somente

\footnotetext{
${ }^{79}$ Em sentido semelhante, Boaventura de Sousa Santos afirma que não existe apenas uma única entidade chamada de globalização, mas "globalizações", porque se trata de uma pluralidade de fenômenos e da contradição de processos, diretamente relacionada a um sistema mundial em transição. Dentre as formas de globalização elencadas pelo autor, predomina a hegemônica, ou de-cima-para-baixo, em que os Estados hegemônicos ou dominantes (em regra os Estados localizados na parte superior do globo terrestre, ou seja, o polo norte) controlam a atividade das multinacionais, a transformação da língua inglesa como predominante, a globalização do fast food estadunidense, a adoção de mesmas leis de patentes, de propriedade industrial, de telecomunicações, entre outros. Isto demonstra o reconhecimento da existência do chamado "localismo globalizado", cujo fenômeno que é local torna-se global, diante da sua conversão em prática universal e a consequente exclusão de práticas alternativas ou minoritárias. Todavia, por mais que tais práticas revelem-se dominantes, elas não detêm a capa-
} 
o significado dos termos, como também o panorama geral e atual dos direitos humanos, os quais enfrentam como principal objeção justamente este caráter econômico e, consequentemente, questões políticas decorrentes da natural competição fomentada entre os Estados. A globalização, entendida como o sentido econômico em escala global, mostra-se, frequentemente, de forma uniformizadora e não pluralista, denotando o risco de uma "[...] mundialização hegemônica que não exprima nada além do que a lei do mais forte" (DELMAS-MARTY, 2003, p. 09).

Revela-se, assim, que por mais necessária que seja a expansão econômica, transpondo fronteiras em um mundo altamente interconectado, não se pode olvidar das diferenças que permeiam os direitos humanos e, que se almeja a construção de uma ordem mundial cosmopolita, deve-se ter em vista um compartilhar de sentidos e não a difusão de um modelo único.

O presente capítulo objetiva demonstrar a emergência deste espaço global sob dois pontos de vista: da primazia da economia e de interesses hegemônicos e dominantes, por um lado e, do outro, a proteção conferida aos direitos humanos, denotando a possibilidade de construção de mecanismos que admitam as diferenças locais, desde que compatíveis com os princípios fundadores comuns desta nova ordem cosmopolita. Pretende tratar de modelos e sistemas de justiça que primem por alcançar os propósitos desta nova ordem, a exemplo da instituição de uma república mundial complementar e subsidiária ou, então, da conversação entre entes estatais e ordens normativas internacionais, embasada no transconstitucionalismo.

\subsection{As RELAÇÕES INTER-ESTATAIS E OS DESAFIOS PARA O COSMOPOLISTIMO}

A sociedade atual, organizada com base no capitalismo e na constante interação entre os Estados, denota a expansão de trocas comerciais, que ocorrem de forma virtual e, muitas vezes, sem a possibilidade de controle pelos Estados. Há a concentração do poder financeiro nas empresas multinacionais, razão pela qual a globalização gera consequências sobre a efetividade dos Estados, sobre a soberania dos territórios, bem como sobre a legitimidade democrática das instituições que atuam globalmente.

Este é apenas um dos aspectos que demonstram que os Estados-nação vêm perdendo, ao longo dos anos, a capacidade de regulação e direção sobre aspectos geopolíticos, como o controle dos fluxos imigratórios, produtivos, mercantis e monetários.

A globalização mostra-se como um desafio para os Estados, na medida em que a racionalidade ocidental sempre tentou, ao longo dos anos, dominar o poder, a política e a economia, por meio do Direito. A globalização é um fenômeno contrário

cidade de evitar formas de resistência, as quais constituem a globalização contra-hegemônica ou de-baixo-para-cima, cujas formas de expressão são o cosmopolistimo e o patrimônio comum da humanidade (SANTOS, 2011). 
a este controle, pois é caracterizada "[...] pela ausência de controle, pela perda de referência, pela liberação de um sistema econômico que repele qualquer tentativa de controle a partir do poder político" (JULIOS-CAMPUZANO, 2013, p. 63-64).

Tais transações econômicas movimentam-se em escalas jamais vistas, alterando a própria forma de organização dos Estados e de concentração de poder, pois há a intensificação de relações de troca, de comunicações e de trânsito para além das fronteiras nacionais, criando redes mais amplas e densas. Por esta razão, "rede" "[...] tornou-se uma palavra-chave, e tanto faz se se trata das vias de transporte para bens e pessoas, de correntes de mercadorias, capital e dinheiro, de transmissão e processamento eletrônicos de informações ou de circulações de pessoas, técnicas e natureza" (HABERMAS, 2001, p. 84).

Estas redes, formadas especialmente sob este viés econômico, ou seja, de circulação de capital, podem conduzir a um acirramento da competição internacional em torno do poder. Tais disputas sempre ocorreram no cenário internacional para a aquisição de novos territórios para exploração ou para a proteção das fronteiras internas contra determinados povos rejeitados, diante de aspectos culturais e/ou políticos.

Isto reflete que não obstante a dominação econômica, pelos mais variados motivos e pretextos, os Estados também conseguem aumentar o seu poderio através do desencadeamento de guerras. Apesar das promessas de paz e da criação da Organização das Nações Unidas (ONU), em 1945, com o objetivo maior de desenvolver mecanismos aptos a possibilitar a segurança internacional, o desenvolvimento econômico, bem como a proteção aos direitos humanos e o progresso social, ainda não se vislumbra a inexistência de conflitos entre os Estados ${ }^{80}$.

Isto é comprovado, por exemplo, pelo grande desenvolvimento das tecnologias e, com isso, a criação de armas nucleares ou o desenvolvimento de robôs de guerra. Exemplificando, Delmas-Marty trata que é possível o advento de um antigo sonho: a criação de robôs autônomos. Todavia, este sonho pode virar pesadelo, na medida em que emergem questionamentos como: No caso de ocorrência de problemas quem será o responsável? Como evitar riscos de erros? Isto direciona a ideia de que os robôs podem contribuir simultaneamente para a guerra e para a paz, bem

\footnotetext{
${ }^{80}$ Por mais que ainda existam conflitos globais entre os Estados, não se pode negar o reconhecimento e o comprometimento internacional com os direitos humanos que, após a Segunda Guerra Mundial, “[...] marca a transformação do Direito Positivo, em particular o de escala nacional, para o açambarcamento de novos conteúdos, com a ampliação da tutela jurídica a todos os seres humanos do planeta, sejam mulheres, crianças, pobres, indistintamente das raças e demais características pessoais que possam justificar uma exclusão sistemática, estabelecendo padrões de ética como pilares da civilização. Desde então os direitos humanos passam a ser amplamente positivados por tratados internacionais, regional (Europa, Américas, África) ou universalmente (ONU). A universalização dos direitos humanos pode ser analisada - embora logicamente não se reduza a isso - sob a ótica da participação dos Estados, aos tratados internacionais, que primam por conjugar, definir e ampliar seus estatutos de proteção" (MORAIS; SALDANHA; VIEIRA, 2013, p. 25).
} 
como as tecnologias podem apoiar o totalitarismo e a democracia (DELMAS-MARTY, 2013, p. $96^{81}$ ).

Estes dois aspectos da globalização revelam um panorama atual que ainda não conseguiu ser solucionado pelo direito internacional moderno. A tão sonhada busca pela paz entre os Estados está ameaçada pelo desenvolvimento das técnicas e processos que, em lugar de conciliarem interesses, acabam fomentando disputas em torno do poder. Diante da necessidade de se buscar a paz, cabe invocar os ensinamentos de Immanuel Kant, em "A paz perpétua”.

Kant, já no ano de 1795 , entendia que enquanto uma comunidade política se vê ameaçada pelo comportamento de outros Estados é impossível que reine a justiça entre os cidadãos. Por outro lado, esta prevalecerá quando o império da lei estiver consolidado em todos os Estados e nas relações internacionais. Defende que o direito cosmopolita não é uma forma fantástica e nem utópica de conceber o direito, mas um "complemento necessário" de código não escrito do direito nacional e internacional existente e o meio para transformar este último em um direito público da humanidade. Delimita o direito cosmopolita às condições da hospitalidade universal, referindo-se ao direito de "não ser tratado com hostilidade" no estrangeiro - no terceiro artigo definitivo (KANT, 2010, p. 46).

Permite-se que as pessoas desfrutem do intercâmbio de ideias e bens com habitantes de outras regiões, não a ponto de instalar-se definitivamente no país visitado - a fim de não abarcar os direitos dos cidadãos -, cuja hospitalidade é entendida no sentido de informar e ser ouvido, condições básicas para tentar estabelecer relações com os habitantes nativos (KANT, 2010). Este direito cosmopolita transcende as pretensões dos Estados, estendendo-se a todos os membros da "comunidade universal", demonstrando um direito e um dever que as pessoas devem aceitar se pretendem tolerar as companhias externas e coexistir pacificamente com elas. Esta é uma forma de rechaçar o colonialismo, entendido como uma forma de injustiça que as pessoas cometem ao visitar países e populações estranhas, tentando conquistá-los (KANT, 2010).

Este raciocínio cosmopolita de Kant baseado na hospitalidade universal indica que cada indivíduo é membro do Estado e do universo, razão pela qual sua tese é baseada no objetivo de romper com os laços dominantes à época, tratando do exercício da liberdade de forma mais ampla. Neste ponto, Kant aproxima-se dos cínicos - pessoas de vida instintiva e errante, fora da sociedade -, cujo destaque reside em Diógenes. Este vivia em um barril, sobrevivia através da mendicância e declarava "Eu sou uma cidadão do cosmos", não refletindo a afirmação como uma crítica ao Estado e à pólis, mas como a defesa de ser um cidadão de todos os lugares, podendo seguir as regras que bem entendesse e não necessariamente as do contexto em que vivia (MOLES, 2007).

Esta forma de vida dos cínicos pode ser entendida como um "cosmopoli-

${ }^{81}$ Cumpre salientar que todas as traduções foram feitas de forma livre pela autora. 
tismo cínico", relacionado à liberdade, à hospitalidade ou aos direitos de um estrangeiro, destinados a assegurar a liberdade pessoal e coletiva. Isto evidencia que cada indivíduo é considerado integrante de uma sociedade de cunho mundial, que engloba a noção unitária de Estado, assim como a pluralidade decorrente das relações entre Estados. É uma totalidade que integra unidade e pluralidade, em uma circularidade que detém a presença do cidadão, face ao direito de caráter cosmopolita, emancipando o ser humano e a proteção de seus direitos.

Seguindo nesta linha de raciocínio, David Held aborda um direito democrático cosmopolita - a base reside na ideia da democracia -, em que é necessário o consentimento ativo dos povos e nações, tendo em vista que a participação deve ser voluntária, pois "Seria uma contradição com a própria ideia de democracia que uma ordem democrática cosmopolita fosse criada por vias não voluntária, ou seja, coercitivas" (HELD, 1997, p. 276 ${ }^{82}$ ).

Em princípio, a população de todo o planeta poderia ser abarcada pela construção de uma estrutura comum, transnacional, mas isto efetivamente depende de recursos políticos e culturais com que conta cada comunidade para participar de um compromisso democrático e transnacional. Assim, os princípios dos Estados e das nações democráticas podem coincidir com os do direito cosmopolita, tendo como consequência a universalização de tais direitos e deveres. Os indivíduos que compõem os Estados e as sociedades cujas instituições foram confirmadas de acordo com o direito cosmopolita podem ser considerados cidadãos, não de sua região ou comunidade nacional, mas de um sistema universal de governo "cosmopolítico" (HELD, 1997, pp. 277-278).

Significa que as pessoas podem dispor de múltiplas cidadanias, pois são cidadãos de suas comunidades políticas imediatas e das redes regionais e globais compreensivas que influem sobre suas vidas. A comunidade política cosmopolita reflete e abarca, em forma e substância, os diversos sistemas de poder e autoridade que operam dentro e através das fronteiras e que, se não forem controlados, constituem a ameaça de uma ordem altamente fragmentada, neomedieval (HELD, 1997, p. 278).

Resta claro que, neste cenário, os Estados-nação novamente "murcham", na forma de uma realocação, pois deixam de ser os únicos centros de poder legítimos dentro de suas próprias fronteiras, mas mais um foco de desenvolvimento legal, reflexão política e mobilização. Isto implica no reconhecimento de que certas tarefas e funções devem ser desempenhadas através de diferentes níveis políticos, a saber: local, nacional, regional e internacional (HELD, 1997, pp. 278-279).

Evidencia-se a relativização da autonomia e soberania dos Estados, diante do desprendimento de fronteiras e territórios fixos, o que é, também, próprio do fenômeno da globalização, como visto acima. Não se trata, por isso, da dissolução dos Estados, mas da existência de uma ordem mundial ou de uma república mundial federal complementar e subsidiária (HÖFFE, 2000, p. 235).

\footnotetext{
${ }^{82}$ Cumpre salientar que todas as traduções foram feitas de forma livre pela autora.
} 
Os Estados continuam responsáveis por assuntos como direito civil, penal, do trabalho, social, das línguas, religiões e culturas, ao passo que esta república mundial tem competência, não apenas subsidiária, mas originária, para promover a paz entre os Estados e para a sua condição prévia: o desarmamento, incluindo a proliferação de armas atômicas, biológicas e químicas, além do Tribunal Mundial Criminal ficar sob sua responsabilidade (HÖFFE, 2000, p. 236).

Sob esta perspectiva, qual seja, de um "cosmopolitismo graduado", os indivíduos são vistos como cidadãos do mundo. Não há um Estado mundial ocupando o lugar dos Estados particulares e o direito cosmopolita não substitui o direito civil "nacional", pois seria o caso de um Estado mundial homogêneo, globalista, em que se é cidadão do mundo no lugar de cidadão do Estado. Trata-se, por outro lado, da não substituição do direito nacional por um direito civil mundial, mas apenas de forma complementar, intercalando as unidades intermediárias macrorregionais e o direito civil que as corresponde. Neste caso, por exemplo, é primariamente um cidadão alemão, francês ou italiano e, logo, um cidadão europeu. É, por isso, primariamente, cidadão do Estado ou da Europa; secundariamente, o outro (Estado ou Europa, dependendo da primeira escolha) e, em consequência, ambas as coisas; por último ou em terceiro lugar é cidadão do mundo, ou seja, cidadão da república mundial subsidiária e federal (HÖFFE, 2000, p. 248).

O cidadão mundial ou cosmopolita é conceituado por Höffe como “[...] aquele que não se atém a fronteiras, que se desloca por todo o mundo, porém que se sente - mais ou menos - em casa em todas as partes por onde anda" (HÖFFE, 2005, p. 394). Há, ainda, graus em que o cidadão pode enquadrar-se: se conserva a língua, cultura e costumes, mas se deixa levar pela língua franca (hoje é o inglês), é um cosmopolita de primeiro grau; se, por outro lado, alcançar uma abertura para o mundo que o faça perceber o estrangeiro, reconhecendo com igualdade de valor, é um cosmopolita de segundo grau; alcançará o grau máximo - terceiro - se levar a sua própria cultura a outro país, mas se deixar marcar pela nova cultura e não abdicar das novas características ao voltar ao seu território natal (HÖFFE, 2005, p. 394).

Constitui-se de uma forma complementar, em que não se escolhe ser cidadão de um determinado Estado ou cidadão do mundo, não há opção entre uma república "nacional" ou "cosmopolítica". Há relação de complementariedade e de subsidiariedade do direito cosmopolítico em relação ao direito nacional. É pela mesma razão, ou seja, pela subsidiariedade e complementariedade da ordem internacional (ou supranacional, neste caso) em relação à ordem nacional, que a União Europeia - uma união política e econômica de Estados -, por exemplo, deixa determinadas matérias para a "margem de apreciação" dos Estados integrantes, selecionando assuntos que competem aos Estados a definição, aplicação e julgamento, se for o caso, como será visto abaixo.

Também não se pode perder de vista que se trata de um projeto em evolução e que, para alcançar a sua plenitude, precisa de etapas a ser cumpridas, sem 
pretender alterar a sistemática já existente. A esta república mundial não é dada a possibilidade de ameaçar a democracia dos Estados nacionais. Deve, ao contrário, melhorar a sua capacidade de atuação e os patamares de Estado de Direito e Democracia já alcançados. Isto tudo deve ser feito a fim de que alguns Estados não sejam "absorvidos" por outros e nem de que as grandes e hegemônicas potências aumentem o seu poderio. São formas de cooperação entre os Estados, que podem, inclusive, contar com mecanismos de participação popular, baseados no consenso e na aprovação destes.

Todavia, antes de tratar destas formas de conversação, convém destacar a necessidade de existência de procedimentos e instituições aptos a permitir esta relação de complementariedade entre uma República Mundial e os âmbitos dos Estados. Avulta a crítica de Danilo Zolo, que entende que a causa principal dos fracassos do pacifismo institucional está na sua feição universalista e centralista, ao supor, com o amparo do pacifismo cosmopolita, que a paz estável possa ser garantida por um governo universal e pela aplicação do marco da "analogia interna". Para ele, o grande problema da defesa de uma jurisdição universal (sociedade civil global) está na aplicação indevida e abusiva desta analogia interna, ou seja, da transposição para a esfera mundial do mesmo tipo de instituições jurídicas e políticas que operam na esfera estatal (ZOLO, 2008, p. 177).

Com a finalidade de demonstrar os sistemas e formas de organização desta estrutura global de proteção aos direitos humanos existentes, convém abordar a variedade de entes e organizações internacionais que compõem este cenário político-jurídico, bem como a necessidade e importância da "conversação" transconstitucional e da Constituição para que haja operabilidade de tais mecanismos, como será abordado no próximo item.

\subsection{Proteção aOS direitos humanos e a importânCia da "CONVERSaÇão" TRANSCONSTITUCIONAL}

Os anseios por paz mundial atravessam os séculos e habitam o imaginário e as ações dos cidadãos. Como foi retratado acima, o cenário global tem se tornado cada vez mais poroso e aberto a mudanças, especialmente pela redução de controle por parte dos Estados, sendo substituído por fluxos e redes de poder político e econômico.

Entretanto, por mais que os Estados não mais detenham o controle sobre todas as ocorrências ao redor do globo, ainda são considerados atores fundamentais para a construção dos sistemas de proteção dos direitos humanos. Além do mais, se, em algum dia, objetiva-se a coexistência de uma república mundial com os Estadosnação tem-se como necessário que haja o consenso e a participação destes.

Além dos Estados, não se pode desconsiderar as ordens jurídicas transnacionais, ou seja, ordens normativas construídas a partir de organizações privadas ou 
quase públicas e que, mesmo não tendo origem estatal, detêm grande pretensão de autonomia perante os Estados. Constituem ordens próprias, que não se restringem ao aspecto econômico e, por isso, não permanecem isoladas no mundo, mantendo relações com os entes estatais, cidadãos e outras organizações ao redor do mundo. Atuam globalmente - como se fossem empresas multinacionais ou organizações não governamentais - e seguem sua própria lógica, não dependendo dos padrões e deveres que devem ser observados no âmbito dos Estados.

Marcelo Neves, ao tratar do entrelaçamento entre ordens jurídicas estatais e transnacionais, destaca a existência de três grandes ordens jurídicas que atuam, atualmente, nos mais variados setores: a nova lex mercatoria, a lex sportiva e a lex digitalis. A primeira é conceituada como "[...] uma ordem transnacional, cuja construção e reprodução ocorre primariamente mediante contratos e arbitragens decorrentes de comunicações e expectativas recíprocas estabilizadas normativamente entre atores e organizações privadas" (NEVES, 2009, p. 189). Há autonomia e auto fundamentação tanto por parte da lex mercatoria como das ordens estatais, havendo a necessidade de intercâmbio entre as ordens, justamente por estarem em constante interação.

Este intercâmbio entre as ordens é de suma importância quando da ocorrência de conflitos entre direitos fundamentais, razão pela qual se torna essencial a ocorrência de "conversação" transconstitucional entre as ordens jurídicas, não importando o tipo. Interessante referir decisões do mais alto tribunal judicial da França em que há o reconhecimento da autonomia da lex mercatoria em relação às ordens jurídicas estatais. Em um caso específico (Putrabali), o Tribunal de Cassação da França reconheceu que uma arbitragem transnacional não está ancorada em nenhuma ordem jurídica nacional, razão pela qual um julgamento arbitral transnacional é uma decisão judicial transnacional. Diante desta circunstância, por mais que a lex mercatoria não tenha como principal objetivo a resolução de questões constitucionais, ao deparar-se com elas, precisa entabular esta "conversação" transconstitucional com os Estados (NEVES, 2009, p. 195).

No que concerne a lex sportiva, trata-se de um entrelaçamento de ordens construídas tendo como base o esporte e constituída por associações transnacionais, com alto grau de autonomia perante os Estados, impactando, principalmente, sobre questões individuais de natureza constitucional, como a liberdade de contratação e profissional. Em virtude da autonomia de tais ordens jurídicas, decorrente especialmente da proibição de que atletas pleiteiem direitos perante a justiça estatal, envolvendo, em regra, questões de cunho constitucional, há a ocorrência de conflitos entre os Estados e esta ordem normativa (NEVES, 2009, p. 197).

Dentre os casos apreciados pelo Tribunal Arbitral do Esporte (TAS) - o mais alto tribunal transnacional do direito esportivo - a autonomia do ente é sustentada nas decisões, embasadas no princípio da igualdade, de cunho eminentemente constitucional, pois "O exercício do esporte no nível internacional não poderia obe- 
decer a uma multiplicidade de regras nacionais potencialmente contraditórias" (NEVES, 2009, p. 199). E, ainda, “[...] basta assegurar que a mesma disciplina esportiva, desde que ela se desenvolva em um quadro internacional, seja submetida às mesmas regras para todos os concorrentes" (NEVES, 2009, p. 199).

Isto evidencia a relação de complementariedade entre o TAS e os tribunais estatais, porque em um conflito versando sobre o acesso à justiça ou a possibilidade de ampla defesa e (versus) a igualdade de julgamento de punições e problemas decorrentes de competições internacionais, deve prevalecer a igualdade, restando os conflitos sob a responsabilidade do tribunal esportivo. Isto não exclui, por óbvio, a competência dos tribunais estatais para a punição de seus jurisdicionados. No entanto, as decisões dos Estados não podem sobrepor-se à do TAS, sob pena de afronta ao princípio da igualdade, que deve prevalecer neste diálogo transconstitucional, quando da ocorrência de conflitos desta natureza.

O último exemplo de ordem transnacional ou "deslocalizada" é a lex digitalis que envolve problemas a respeito do direito da Internet. De acordo com Marcelo Neves, neste caso destaca-se a atuação do ICANN - Corporação da Internet para Atribuição de Nomes e Números -, entidade responsável por regular o sistema de nome de domínio na Internet. A questão reside no fato de que a ICANN tem origem governamental nos Estados Unidos, surgindo em 1998, sob a administração do presidente Bill Clinton. A Corporação nasceu mediante a determinação da Administração Nacional de Telecomunicações e Informação (NTIA), mas tem como objetivo principal a representação de interesses públicos da comunidade global da Internet (NEVES, 2009, p. 207).

Nesta ordem, a ICANN possui, de certa forma, limitação de atuação nos Estados Unidos, pois de acordo com o seu regulamento, fica submetida ao direito estadunidense, mas, por outro lado, tem plena autonomia de determinação e vinculação nos Estados em geral. Assim, nos demais Estados, possui “'[...] um poder enorme de regulação jurídica em matéria de determinação do nome de domínio, tornando os judiciários estatais dependentes de suas orientações e decisões" (NEVES, 2009, p. 208).

Destaca-se a importância de seus mandamentos especialmente em conflitos versando sobre direitos de informação, de liberdade de expressão, de propriedade intelectual, de imagem e nome, os quais podem determinar diferentes decisões entre o poder judiciário estatal envolvido no litígio e o estabelecido pelo ICANN, estabelecendo-se, assim, a conversação transconstitucional. A peculiaridade neste caso é que se trata de um transconstitucionalismo assimétrico, justamente pela primazia dos Estados Unidos que "[...] detêm, em última instância, o poder de controlar o sistema de atribuição de nomes de domínio da internet em todo o globo terrestre, prevalecendo sobre qualquer Estado" (NEVES, 2009, p. 210).

Além destas três ordens não se pode desconsiderar a importância de atuação das Organizações Não Governamentais (ONGs) transnacionais, a exemplo do 
Comitê de Basileia de Supervisão de Operações Bancárias (é formado por uma estrutura mista de atores públicos e privados, não estando vinculado a tratados ou convenções internacionais); e da Al-Qaeda (construída sobre uma complexa rede de comunicações, retratando o lado negativo do transconstitucionalismo) (NEVES, 2009, pp. 213-216). São, ainda, consideradas um elemento essencial na constituição de uma república mundial - sustentada acima por Höffe -, porque para que haja efetividade das virtudes cosmopolíticas é necessária a criação de organizações destinadas à sociedade mundial. Não deve haver apenas uma única organização comum a todas estas virtudes, mas sim diferentes organizações que estabeleçam uma parceria recíproca (HÖFFE, 2005, p. 400).

O estabelecimento e a delimitação destas ordens transnacionais são essenciais ao abordar o chamado "Estado pós-nacional", terminologia utilizada por Habermas no sentido de que a internacionalização do direito traz implicações para o Estado Nacional e para o constitucionalismo a ele relacionado. Este cenário globalizado exige um repensar na forma do Estado nacional moderno (HABERMAS, 2001).

Recorde-se que até o século XVII formaram-se Estados caracterizados pelo "domínio soberano" sobre determinado território e que eram superiores em capacidade de controle às formações antigas, a exemplo das cidades-Estados. Com o passar do tempo, este Estado restou dependente da ordem capitalista e, ao tornar-se, no século XIX, "Estado nacional", vem sendo ameaçados os mecanismos de controle e poder, diante da economia globalizada em que se vive. Deve as funções estatais ser preenchidas e repassadas a outros organismos políticos que assumam, de algum modo, uma economia transnacional (HABERMAS, 2001, p. 69).

Habermas defende a construção de instituições supranacionais ou, ainda, projetos de cooperação maiores, como a União Europeia. Tais regimes surgem “[...] não apenas nas regiões monetárias unificadas, que diminuem os riscos das oscilações da cotação, como também unidades políticas maiores com competências divididas de modo hierárquico" (HABERMAS, 2001, pp. 69-70). Por isso, há a necessidade de que os Estados vinculem-se a procedimentos cooperativos obrigatórios em uma sociedade cosmopolita, tornando-se cada vez mais necessário o surgimento de uma consciência da obrigatoriedade da solidariedade cosmopolita nas sociedades civis e esferas públicas políticas dos regimes em desenvolvimento. É uma mudança de consciência que deve partir do interior das fronteiras dos Estados, ou seja, dos cidadãos, para que sejam compreendidos como membros do quadro de uma comunidade internacional, estando submetidos a uma cooperação incontornável e, também ao respeito recíproco de interesses (HABERMAS, 2001, pp. 72-73).

Habermas, apesar de entender não ser possível a organização de um Estado mundial - em virtude da independência, dos caprichos e das peculiaridades dos Estados outrora soberanos -, afirma ser necessário que os primeiros destinatários deste projeto sejam os movimentos sociais e ONGs. Quer dizer, membros ativos de uma 
sociedade civil que vai além de fronteiras nacionais para que seja possível a "[...] institucionalização de procedimentos para a sintonização mundial de interesses, para a universalização dos interesses e para a construção criativa de interesses comuns [...]" (HABERMAS, 2001, p. 74).

A universalização e construção de interesses comuns residem, talvez, nos maiores desafios colocados frente à criação deste Estado mundial. Há a necessidade de abertura do Estado constitucional e de sua simbiose com a "nação" para que a solidariedade que deve existir entre os cidadãos renove-se em um nível mais abstrato no sentido de um universalismo sensível às diferenças. Por esta razão, retorna-se aos ensinamentos de Marcelo Neves, ao tratar de problemas jurídicos que perpassam diferentes níveis e estruturas transnacionais, como visto acima com a lex mercatoria, sportiva e digitalis.

A importância reside na noção de que a Constituição “[...] é a instância reflexiva mais abrangente do sistema jurídico, permeando-lhe todos os âmbitos de validade, o material, o temporal, o pessoal e o territorial. Enquanto norma(s) de normas, ela perpassa transversalmente todo o sistema jurídico, dando-lhe consistência" (NEVES, 2009, p. 59). E é esta consistência da Constituição dos Estados que se revela tão importante no cenário jurídico-político atual, através da necessidade de que este instrumento que faz parte do direito estatal possa dialogar com as demais ordens jurídicas supranacionais, internacionais e transnacionais.

Este diálogo entre as cortes é propiciado pelas "pontes de transição", ou seja, por entrelaçamentos entre ambos os sistemas, de forma a desenvolver uma racionalidade transversal específica. A forma mais relevante desta transversalidade é a desenvolvida entre ordens jurídicas, perpassando os juízes e tribunais, mas também é possível a ocorrência de incorporação de normas de outra ordem, sem que haja a intermediação entre tribunais (NEVES, 2009, p. 118). Isto permite, por exemplo, a conversação entre Parlamentos ou entre órgãos do Poder Executivo, mediante troca de experiências ou, quem sabe, a regulação de determinadas matérias por uma república mundial e outras sob a competência dos Estados, atendendo às particulares e diferenças locais.

Esta forma de transversalidade ou de transconstitucionalismo é a que autoriza a citação dos precedentes de outras cortes, constituindo-se em uma forma de uma autoridade persuasiva. Significa a existência de um aprendizado construtivo e cooperativo entre os entes, fundando-se em uma forma muito importante de diálogo entre os órgãos jurisdicionais. Isto porque atualmente as questões relacionadas aos direitos humanos não mais se restringem às fronteiras dos Estados, razão pela qual o direito constitucional, por si só, torna-se limitado para resolver todos os litígios.

Não obstante esta limitação do direito constitucional, os temas que dizem respeito a ele devem ser tratados com a máxima seriedade e importância, para que o transconstitucionalismo não precise assumir uma postura bélica em face daqueles Estados que não admitem uma Constituição em sentido moderno, a serviço de 
uma racionalidade transversal entre direito e política. Também, deve ser combatido o "provincianismo constitucional", devendo o Estado estar aberto a esta nova ordem, uma vez que não há a possibilidade de dela ser excluído, pois há conflitos e relações com os outros Estados e órgãos e os Estados não estão isolados no mundo. Inclusive porque estes diálogos tendem, em regra, a beneficiar os Estados, na medida em que os conflitos sempre existirão e formas de resolução dos mesmos, desde que em consonância com os princípios e a cultura do Estado, são bem-vindos, especialmente pelo caráter global dos conflitos.

Além do mais, há outros autores que também propõem formas de entrelaçamento entre entes Estatais e supraestatais, a exemplo de Anne-Marie Slaughter e William Burke-White que entendem que "O futuro do direito internacional é doméstico". Defendem, dentre outros aspectos, a necessidade de fortalecimento das instituições internas dos governos nacionais, a exemplo da formação e inclusão de "redes governamentais" como mecanismos de governança global. Essas amplas redes voluntárias conectam autoridades de diferentes países em campos ou esferas de responsabilidade similares, fornecendo um meio eficaz para aparelhar sistemas regulatórios nacionais na busca de objetivos comuns, quer dizer, internacionais. Tais redes podem ajudar a harmonizar políticas nacionais e a fornecer um suporte para os esforços das autoridades internas em relação aos seus próprios governos (SLAUGHTER; BURKE-WHITE, 2006, p. 33483).

Estas redes de governo nacional de todos os tipos já estão operando através das fronteiras para regular pessoas físicas e jurídicas que operam em uma economia global, combater o crime mundial e resolver problemas comuns em uma escala planetária. Realizam uma série de funções que melhoram a eficácia da governança interna através da construção de confiança e estabelecimento de relações entre os seus participantes a fim de fomentar a cooperação. Trocam informações e práticas, desenvolvendo bases de dados ou, ainda, na esfera judicial, há o intercâmbio de abordagens diferentes para questões jurídicas similares (SLAUGHTER; BURKEWHITE, 2006, pp. 334-335).

Isto evidencia a construção de um círculo de mútuo aprendizado entre os Estados e organizações transnacionais, na medida em que, por exemplo, na esfera judicial, não há a simples transposição de decisões, mas o embasamento para a reflexão sobre as mesmas, de forma que o diálogo seja efetivado e proporcione resultados positivos e específicos para o Estado em questão. Saliente-se, novamente, que a construção de uma ordem mundial em defesa dos direitos humanos não pode partir de uma uniformização ou da constituição de órgãos ou Estado superiores e detentores de práticas a serem seguidas pelos demais. Deve refletir uma prática colaborativa e que demanda atenção de todos os atores envolvidos, de forma que todos possam contribuir na construção de um bem comum a todos.

Este cenário denota a incessante modificação do direito vigente que não

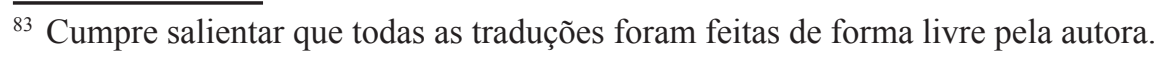


deve ficar a cargo apenas dos parlamentares, refletindo, no mais das vezes, um instrumento de atuação política e partidária. $\mathrm{O}$ direito tem sido construído, cada vez mais, no caso concreto, quer dizer, na resolução dos litígios por juízes e tribunais. Gustavo Zagrebelsky, ao tratar do direito "dúctill", entende que o legislador deve resignar-se a ver as leis como "parte" do direito e não como "todo o direito". Isto evidencia a grande responsabilidade dos juízes, ao garantirem a complexidade estrutural do direito no Estado constitucional, quer dizer, os garantes da necessária e dúctil coexistência entre lei, direitos e justiça (ZAGREBELSKY, 2007, p. 153).

A defesa deste direito dúctil por Zagrebelsky demonstra que os valores e princípios nem sempre são harmônicos, denotando que, em verdade, são cada vez mais conflituosos, fazendo com que a estrutura destes valores e princípios não tenha um caráter absoluto, pela impossibilidade de convivência. Por esta razão, novamente invoca-se a necessidade de que pluralismo permeie as ordens jurídicas na construção de uma ordem cosmopolita. Abaixo será abordada a manutenção deste pluralismo na União Europeia através da margem de apreciação conferida aos juízes estatais, bem como a necessidade de diálogo entre os organismos transnacionais, Estados e os cidadãos.

\section{OS ATORES INTERNACIONAIS E AS QUESTÕES QUE TRANSPÕEM BARREIRAS TEM- PORAIS E TERRITORIAS: A NECESSIDADE DE DIÁLOGO}

Diante do panorama que foi apresentado, resta evidente que os problemas envolvendo direitos humanos e outras questões de âmbito internacional não são mais resolvidos por uma única ordem, fechada em seu território. Os Estados-nação precisam abrir as suas fronteiras não apenas à comercialização de produtos, como também para o intercâmbio de informações, precedentes, julgados e, assim, compartilhando valores universais, adaptados às realidades nacionais, possam coexistir de forma cooperativa, buscando, quiçá, alcançar a paz universal.

Isto é uma das razões que inspira a existência e manutenção da União Europeia, pois por mais que tenha surgido com o precípuo interesse econômico, com a finalidade de facilitar as trocas econômicas entre os Estados, há, além deste perfil decorrente da globalização econômica, a percepção da necessidade de proteção aos direitos humanos. Esta proteção é, em grande medida, reforçada pela existência do Tribunal Europeu de Direitos Humanos (TEDH) e, em consequência, da delegação de determinadas matérias à competência dos Estados, conhecida como margem de apreciação.

A existência da União e de tais mecanismos, ainda que em alguns pontos sejam sujeitos à crítica - a exemplo de medidas xenófobas e de restrição à imigração -, invocam a proposição suscitada por alguns autores explanados acima acerca da existência de diálogo e da importância de conversação entre as cortes e parlamentos. Tais medidas são necessárias no âmbito global para que as decisões e regras não 
sejam impostas de cima-para-baixo, mas que sejam construídas coletivamente, com a colaboração, inclusive, da população envolvida.

Mostra-se relevante refletir sobre a situação vivenciada atualmente, em que aprende com as dificuldades e consequências da globalização, ao mesmo tempo em que se anseia por maior proteção aos direitos humanos. Não obstante, o indivíduo é considerado o cerne de todo este processo, razão pela qual também devem ser buscadas medidas e alternativas em que haja espaço para a discussão popular ou pública sobre os rumos a serem adotados pelos Estados, organizações ou união supraestatal.

O objetivo deste capítulo consiste em reunir informações sobre a União Europeia, especialmente no que concerne à subsidiariedade e complementariedade das decisões da Corte de Direitos Humanos, deixando espaço para a margem de apreciação dos Estados. Ainda, pretende observar a possibilidade de conversação entre as ordens jurídicas e normativas estatais e internacionais, quer dizer, a construção de diálogos entre Parlamentos, Cortes e cidadãos, principalmente através da utilização das Tecnologias de Comunicação e Informação (TICs).

\subsection{O Sistema da UNIÃo EUROPEIA E A MARGEM de APRECIAÇÃo dos ESTADOS}

A União Europeia (UE) é constituída por uma cooperação econômica e política com características únicas. No seu início, em 1951, era formada apenas pela Bélgica, Alemanha, França, Luxemburgo e os Países Baixos e tinha como principal objetivo a reunião de países com relações comerciais, a fim de que se tornassem economicamente dependentes, o que implicaria na redução de relações conflituosas entre os mesmos.

Com o passar dos anos a União Europeia foi aumentando o número de Estados-Membros chegando, atualmente, ao patamar de vinte e oito países desde a adesão da Croácia em 01 de julho de 2013. É, portanto, um enorme mercado único em permanente e constante evolução (UNIÃO EUROPEIA, 2014a).

É de notório conhecimento que a União Europeia, no decorrer de sua história, passou de uma união meramente econômica para uma "[...] organização que abrange domínios de intervenção variados que vão da ajuda ao desenvolvimento à política ambiental. A mudança de nome de 'CEE' para 'União Europeia (UE)' em 1993 reflete essa evolução” (UNIÃO EUROPEIA, 2014b). Esta evolução abrange, sob um aspecto econômico e, no âmbito dos países integrantes, a possibilidade de livre circulação de pessoas, bens serviços e capitais, sendo o "mercado único" ou "mercado interno" o principal motor da economia europeia. Ainda, a unificação em torno de uma moeda única, o euro, contribuiu para melhorar o nível de vida, a estabilidade e prosperidade dos países envolvidos.

Ademais, trata-se de uma União baseada nos princípios do Estado de Direito, porque todas as suas ações são oriundas de tratados aprovados de forma voluntária e democrática pelos Estados que a compõem. Isto é comprovado por um 
segundo objetivo da UE, qual seja, a proteção e promoção dos direitos humanos no âmbito de sua existência, assim como no resto do mundo. Assim, desde a assinatura do Tratado de Lisboa, em 2009, todos os direitos - como liberdade, dignidade humana, democracia, igualdade, respeito pelos direitos humanos - estão reunidos em um único documento, a Carta dos Direitos Fundamentais, sendo obrigação das instituições europeias e dos Estados-Membros respeitar seus mandamentos (UNIÃO EUROPEIA, 2014b).

Afora estas previsões, a União Europeia busca em todos os âmbitos de atuação tornar suas instituições mais transparentes e democráticas. Por exemplo, o Parlamento Europeu tem os seus poderes eleitos por sufrágio universal direto, os quais têm sido progressivamente alargados, assim como o papel dos Parlamentos nacionais que colaboram com a União. Isto reflete, inclusive, maior participação popular, como será analisado abaixo.

Esta necessidade de participação e engajamento popular é destacada por Habermas ao firmar a necessidade de um "procedimento de legitimação democrática comum" que, no entanto, ainda não foi satisfeita. Seria um procedimento tendente a ir além do código eleitoral e das esferas públicas dos Estados, formando "[...] uma práxis comum de construção das opiniões e vontades que se alimente das raízes de uma sociedade civil europeia e se desdobre em uma arena com dimensões europeias" (HABERMAS, 2001, p. 127).

Isto decorre do que foi invocado acima por Kant, quer dizer, da existência do fundamento de solidariedade entre os povos. Pela mesma razão, somente pode-se falar em um "povo europeu", na medida em que haja a confiança e sentimento de pertencimento a esta comunidade, de forma que os cidadãos interessados coloquem as suas “[...] preferências próprias abaixo das exigências de uma autoridade estatal "que impõe obrigações"” (HABERMAS, 2001, p. 128).

Marcelo Neves, ao analisar a questão, também verifica um déficit na existência de um "povo constitucional europeu", sendo necessária a busca de uma identidade europeia como base de uma Constituição supranacional. Defende o surgimento de uma Constituição supranacional transversal no plano regional, para que haja a formação de uma esfera pública forte, quer dizer, "[...] relevante para os procedimentos, que possa servir à abertura do sistema político e, assim, sirva como instância de sua heterolegitimação" (NEVES, 2009, p. 105).

A criação de uma identidade europeia não pode ser imposta de forma homogênea, mas deve ser construída por um povo capaz de determinar e de influenciar nos procedimentos políticos de decisão. Deve existir a circulação e articulação entre a administração, governo, Parlamento e povo, para que seja possível a democratização dos processos e, consequentemente, da União como um todo.

Diante desta perspectiva de democratização e participação dos EstadosMembros nas tomadas de decisão e nos rumos da União, convém retratar um mecanismo que, vislumbrado sob a perspectiva de proteção aos direitos humanos, enuncia 
o princípio da transferência de poder de decisão aos Estados-Membros. Reflete, ainda, o caráter complementar e subsidiário da União em relação aos Estados-Membros. Trata-se da chamada "margem de apreciação".

É uma forma de interpretação utilizada pelo Tribunal Europeu de Direitos Humanos com a finalidade de deixar uma margem de discricionariedade aos EstadosMembros para fixar o conteúdo e alcance dos direitos da Convenção Europeia dos Direitos do Homem, levando em consideração aspectos jurídicos, sociais e culturais. É um modo de interpretação que não está previsto expressamente no texto da Convenção Europeia, mas que é aplicado a partir da ideia de que um direito não pode ser julgado em abstrato, omitindo-se marcos cultural e econômico que o circunda ${ }^{84}$.

É uma forma de salvaguardar os direitos humanos, porque “[...] eles não são definidos com precisão nos próprios textos internacionais, mas admitidos a título temporário em casos de circunstâncias excepcionais, ou a título permanente, com referência às 'restrições necessárias numa sociedade democrática'" (DELMASMARTY, 2003, p. 84). Consiste em um mecanismo apto a conjugar o universalismo dos direitos humanos com o relativismo das tradições nacionais, permitindo uma forma de autonomia mitigada aos Estados-Membros, já que há a possibilidade de controle supranacional, especialmente quanto à legalidade e/ou proporcionalidade da medida, a possibilidade de impetração de recurso em face da decisão, entre outros.

Um exemplo significativo desta apreciação por parte dos Estados-Membros reside na questão sobre liberdade religiosa. De acordo com o artigo $9^{\circ}$, da Convenção Europeia de Direitos do Homem, há a previsão do direito de liberdade de pensamento, de consciência e religião, no sentido de qualquer pessoa tem direito a estas liberdades para: "[...] mudar de religião ou de crença, assim como a liberdade de manifestar a sua religião ou a sua crença, individual ou colectivamente, em público e em privado, por meio do culto, do ensino, de práticas e da celebração de ritos" (TRIBUNAL EUROPEU, 2014). A liberdade abrange, também, a manifestação da religião ou convicções, de forma individual ou coletiva, a qual não pode ser "[...] objecto de outras restrições senão as que, previstas na lei, constituírem disposições necessárias, numa sociedade democrática, à segurança pública, à protecção da ordem, da saúde e moral públicas, ou à protecção dos direitos e liberdades de outrem" (TRIBUNAL EUROPEU, 2014).

\footnotetext{
${ }^{84}$ Mireille Delmas-Marty afirma que "[...] é pelas próprias disposições da Convenção (artigo 26, que coloca o princípio denominado de dupla competência, ora do juiz interno e do juiz internacional) que repousa o reconhecimento de uma margem nacional de apreciação. Reconhecimento de simples bom senso, dir-se-ia: a partir do momento em que o juiz nacional é competente, sob reserva do estatuto da Convenção em direito interno para aplica-la, e a partir do momento em que ele intervém necessariamente antes do juiz europeu, parece razoável levar em conta sua apreciação, a menos que se trate de um daqueles casos de ordem pública que supõe um conhecimento concreto da situação. Dito isso, não se trata senão de uma 'margem' de apreciação, e não de uma apreciação soberana dos Estados, que culminaria por negar o próprio princípio do controle supranacional” (DELMAS-MARTY, 2003, p. 85).
}

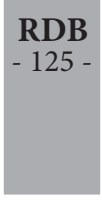


Cabe invocar o caso Leyla Sahin x Turquia - a sentença é de 29 de junho de 2004 -, cuja decisão do TEDH traz o reconhecimento da margem de apreciação por parte do Estado - no caso, a Turquia. Trata-se de uma demanda ajuizada contra a República da Turquia, por uma cidadã turca - Leyla Sahin -, em 1998, sob a alegação de proibição de utilização do véu islâmico em estabelecimentos de ensino superior, o qual constituía uma violação aos direitos e às liberdades previstos nos $\operatorname{artigos} 8^{\circ}, 9^{\circ}, 10$ e 14, da Convenção Europeia de Direitos do Homem, bem como ao artigo $2^{\circ}$, do Protocolo número 01.

A demandante, praticante da religião muçulmana, estudava medicina na Faculdade de Medicina da cidade de Istambul e, a partir de fevereiro de 1998, começou a viger uma comunicação interna - oriunda da reitoria da Universidade - impedindo a circulação de estudantes com a cabeça coberta, ou seja, utilizando o véu islâmico, assim como os estudantes que tenham barba. Diante da contínua utilização do véu pela acadêmica, após o trâmite de um processo administrativo, a mesma foi expulsa da instituição pelo período de um semestre.

Depois de acionar todos os meios de impugnação legais existentes no ordenamento jurídico turco, sem obter êxito, ingressou com a ação no TEDH. Interessa referir as questões analisadas pelo Tribunal Europeu: a liberdade de manifestar a religião pode ser restringida por razões de ordem pública com a finalidade de preservar o princípio da laicidade, bem como de que os estudantes possam trabalhar e conviver em um ambiente de serenidade, tolerância e ajuda mútua, sem que haja o impedimento por pertencimento à determinada religião; a ingerência tem um fim legítimo ao proteger direitos e liberdades alheios em uma sociedade democrática, em que coexistem muitas religiões em uma mesma população; pode o Estado limitar o uso do véu islâmico se prejudicial aos direitos e liberdades alheios e à ordem e segurança públicas; trata-se da aplicação mútua dos princípios da laicidade e igualdade, bem como de valores do pluralismo, do respeito aos direitos alheios e, em particular, da igualdade dos homens e mulheres diante da lei, sendo cabível que as autoridades interpretem como contrários a estes valores o uso de distintivos religiosos, a exemplo do véu muçulmano. Diante destes e outros argumentos, o TEDH reconheceu a "margem de apreciação" que possuem os Estados-Membros, concluindo que a regulamentação da Universidade de Istambul sobre a limitação de uso do véu e as medidas correspondentes a ela estão justificadas, podendo, inclusive, serem consideradas necessárias em uma sociedade democrática (MARGEN, 2014).

Este julgamento foi seguido por outro, desta vez envolvendo a França, acerca da proibição de ensino religioso em escolas públicas do país. É um caso peculiar, porque mesmo que o "Tratado que estabeleceu uma Constituição para a Europa" tenha sido rejeitado em referendo realizado na França e, portanto, não tenha entrado em vigor, o mesmo foi invocado para verificar a sua compatibilidade com a Constituição francesa, submetido à decisão do Conselho Constitucional da França. Isto que dizer que uma Constituição supranacional, mesmo não tendo sido aprovada 
pela população francesa, acabou por fazer parte de um julgamento pela Corte francesa ou, em outras palavras: "[...] o direito supranacional foi interpretado conforme norma de direito internacional por um órgão de controle de constitucionalidade de um Estado, para afirmar a peculiaridade de um princípio de direito constitucional" (NEVES, 2009, p. 240).

Invocou-se o artigo $9^{\circ}$, da Convenção Europeia de Direitos do Homem - liberdade religiosa - que, neste caso, dispôs sobre a existência de uma república laica na França. A particularidade do Estado francês reside em utilizar o princípio da laicidade estatal para proibir o ensino religioso nas escolas públicas - e não, como nos demais Estados da União Europeia, para vedar a obrigatoriedade do ensino religioso. Partindo desta constatação, o Tribunal Constitucional (e não o TEDH) julgou que a liberdade religiosa prevista na Convenção deixa uma "margem de apreciação" aos Estados signatários da Convenção, permitindo que cada um regule, com certa margem de discricionariedade, a liberdade religiosa nas escolas públicas (NEVES, 2009, p. 241).

Esta decisão reflete que, mesmo não tendo assinado formalmente o Tratado, o Estado francês, através de interpretação transconstitucional, quer dizer, além da Constituição do Estado e mediante a adequação de princípios de um tratado internacional, aplicou-os ao direito interno. Isto demonstra especialmente em âmbito da União Europeia, a existência de um sistema de vários níveis que permite a resolução dos problemas relacionados aos direitos humanos.

Há a possibilidade de que os órgãos jurisdicionais dos Estados não fiquem restritos tão-somente ao ordenamento jurídico interno, mas que tenham a consciência e a competência para retirar pontos em comum de decisões de outros órgãos e/ ou tribunais baseadas, inclusive, em tratados internacionais. É claro que não se deve fazer uma simples transposição das decisões sem o devido senso crítico e reflexivo, pois cada sistema detém as suas particularidades. É necessário retirar o cerne das fundamentações e aplica-las, mediante processos de interpretação e especificação, ao caso concreto. Para tanto, é imperiosa a realização de diálogo entre as Cortes, entre os juízes, entre parlamentares e, também, entre as opiniões dos cidadãos.

Este diálogo é essencial - como já vislumbrado acima - para a construção de uma identidade europeia por processos de cooperação e solidariedade entre os órgãos, instituições e indivíduos. Trata-se de elemento imprescindível para a efetivação de uma república mundial federal complementar e subsidiária que, antes de abranger o território do globo terrestre, pode e deve começar - se é que já não começou - pela União Europeia devido ao seu alto grau de evolução.

Mostra-se relevante repetir que a União Europeia é pioneira e um exemplo de aliança econômica e comercial, que permite não somente a livre circulação de pessoas e mercadorias, como também o intercâmbio entre decisões, ideias, soluções de conflitos, deixando aos Estados-Membros certa margem de discricionariedade na resolução de problemas jurídico-políticos. Para a construção de um todo harmônico 
e, consequentemente, para a redução de conflitos e alcance da paz mundial, é necessária a união dos relativismos e particularidades de cada sociedade e não a universalização de valores impostos.

Para que coexistam sistemas de proteção em diferentes níveis - local, nacional, regional ou supranacional e internacional - é imperiosa a participação e atuação não somente de entes estatais e organizações internacionais, como também dos cidadãos. Recorde-se, por exemplo, o pensamento de Habermas exposto acima no sentido de que os primeiros destinatários de uma república mundial são justamente os cidadãos, especialmente os organizados em movimentos sociais e ONGs. Isto porque o indivíduo é o cerne de todo o sistema e, portanto, o foco de atuação deve ser baseado nele.

Ao refletir sobre os movimentos sociais organizados através dos meios de comunicação eletrônicos, a exemplo da Internet, Manuel Castells refere o protagonismo dos indivíduos: "Há geralmente um punhado de pessoas, às vezes uma, no início do movimento. De hábito, os teóricos sociais chamam essas pessoas de agências. Eu as chamo de indivíduos" (CASTELLS, 2013, p. 17-18). Esta assertiva reafirma a necessidade de que sistemas de proteção aos direitos humanos em múltiplos níveis sejam pensados e construídos com base nas expectativas, nas opiniões e nos posicionamentos dos cidadãos. É o que, por exemplo, a União Europeia vem tentando fazer ao utilizar o mecanismo virtual "A sua voz na Europa", que será detalhado abaixo.

\subsection{Possibilidades e desafios para a implementaÇão de UM diálogo entre ESTADOS, ORGANIZAÇÕES INTERNACIONAIS E CIDADÃOS}

Neste mundo cada vez mais permeado pela rapidez dos processos, globalização da economia e utilização da informática, o indivíduo também tem alterado a condição de mero expectador de programas e ações governamentais, para o patamar de cidadão, engajado e preocupado com os problemas que envolvem o ambiente em que habita. Isto vem sendo propiciado, ao longo dos anos, pelo advento das comunicações, a exemplo da transmissão de dados e informações pela televisão.

Com o passar do tempo outros mecanismos eletrônicos têm sido empregados com a finalidade de que o cidadão não tenha apenas maiores possibilidades de lazer e diversão, como também para que possa influenciar na esfera pública que o cerca. Atualmente, ao se falar em Tecnologias de Comunicação e Informação (TICs), o grande destaque reside no papel que vem sendo desempenhado pela Internet.

A Internet é considerada um ambiente em que há facilidade de utilização, rapidez na transmissão das informações e transposição de barreiras temporais e territoriais, pois um fato noticiado em determinado local do globo é rápida e instantaneamente conhecido por indivíduos localizados no lado oposto, a milhares de quilômetros de distância. Por estas características inovadoras e peculiares, a Internet tem se revelado em um espaço que, potencialmente, propicia grande liberdade de 
expressão e de manifestação pelos indivíduos.

É um ambiente em que o cidadão torna-se protagonista daquilo que pretende ler e tomar conhecimento, não necessitando da existência de um profissional especializado que faça um filtro prévio ao determinar quais são os conteúdos importantes para aquela pessoa ou local. Mostra-se como um espaço atrativo, em que é o próprio indivíduo que seleciona aquilo que entende útil e necessário acessar para, então, poder compartilhar com outros internautas.

Isto significa que "[...] a Internet promove a liberdade de expressão em seus dois componentes: receber informações, mas principalmente expressar-se, como comunicar as informações e ideias. Tornou-se mais difícil para os governos ocultarem as informações que não desejam divulgar" (DELMAS-MARTY, 2013). É claro que o meio não é construído apenas de pontos positivos, cabendo destacar os riscos de sua utilização e, talvez, dependência.

É o caso, por exemplo, do monitoramento digital, pois ao mesmo tempo em que há sobrecarga de informações e maior liberdade de expressão, há a possibilidade de vigilância adicional que tende ao controle generalizado. Significa que "[...] as TIC são uma maneira sem precedentes na história de cruzar e compartilhar conhecimentos, mas também para rastrear seres humanos como produtos ou como os animais perigosos são seguidos [...]” (DELMAS-MARTY, 2013, p. 92).

São, novamente, mostras dos efeitos contraditórios da globalização e que devem atentar aos cidadãos sobre os riscos da utilização de tais mecanismos que, em princípio, apenas revelam um aspecto (o positivo) de sua face de dois lados. Há a necessidade de, ao abordar mecanismos que possibilitam maior participação popular, reter com ressalvas as iniciativas e o potencial democrático da rede ${ }^{85}$.

Todavia, apesar deste posicionamento crítico, convém retratar os objetivos e as propostas da iniciativa da União Europeia tendente a potencializar a participação e o diálogo dos cidadãos com os entes governamentais e supraestatais. Trata-se de um mecanismo de participação online, intitulado "A sua voz na Europa", que foi criado no âmbito da "Elaboração Interactiva de Políticas" da Comissão Europeia, em conformidade com os "Princípios e regras mínimas de consulta ${ }^{86 "}$, visando a melho-

\footnotetext{
${ }^{85}$ Em sentido contrário, a perspectiva otimista de Pierre Lévy "A espantosa disponibilidade das informações, de todas as espécies, respeitantes à vida política, assim como o frequentar de fóruns de discussão civilizados e bem organizados, tornam o debate político cada vez mais 'transparente' e preparam uma nova era do diálogo político que conduz a democracia a um estádio superior: a ciberdemocracia. [...] A luz do ciberespaço tornará o Estado mais transparente e os serviços administrativos irão ser prestados em linha. O debate político far-se-á cada vez mais em comunidades virtuais bem informadas e habituadas às sondagens electrónicas sobre todos os assuntos. A vida urbana e a democracia local utilizarão de modo crescente a via da rede" (grifos no original) (LÉVY, 2003, pp. 123-128).

86 "A interacção entre as instituições europeias e a sociedade reveste várias formas: - em primeiro lugar, através do Parlamento Europeu, representante eleito dos cidadãos da Europa; - através dos órgãos consultivos institucionalizados da UE (Comité Económico e Social e
} 
rar a governança europeia e o processo legislativo (A SUA VOZ, 2014a).

Reflete a ideia que vem sendo desenvolvida desde o ano de 2001 quando foi aprovado o Livro Branco relacionado à Governança Europeia. O embasamento reside na sustentação da premissa de que é necessário governar melhor em conjunto, ou seja, através da atuação das instituições europeias e dos Estados-Membros. É possível fazê-lo de acordo com o direito positivado nos tratados, não necessitando esperar pelos resultados de uma nova conferência intergovernamental. É uma atuação e cooperação conjunta entre o Parlamento, o Conselho, a Comissão e os governos nacionais de forma que os cidadãos vejam-se, cada vez mais, refletidos nos projetos e atos da União Europeia (COMISSÃO, 2002b).

Isto é decorrência do método comunitário que produz regras aplicáveis em todos os contextos nacionais, garantindo-se a segurança jurídica. É preciso que haja o enfoque nos cidadãos, pois estes “[...] questionam não só a eficácia das normas 'de Bruxelas' como as condições de sua elaboração. O advento de uma consciência democrática reforça a necessidade de responsabilidade e de proporcionalidade no exercício dos poderes conferidos às instituições europeias [...]" (COMISSÃO, 2002b). A postura ativa e reflexiva dos cidadãos implica, consequentemente, na necessidade de transparência, clareza e aceitação das críticas por parte das instituições da União Europeia e, também, dos próprios Estados-Membros.

Diante de tais razões, objetivou-se a criação de um site que reúna, em um único espaço, consultas, fóruns de debates e outras ferramentas que permitam ao cidadão desempenhar um papel ativo na elaboração das políticas e projetos da União Europeia. O espaço é dividido em três seções, quais sejam, "Consultas"; "Debates"; "Outras ferramentas" "87 (A SUA VOZ, 2014b).

No item "Consultas" há vinte e três tópicos abertos para o recebimento de opiniões por parte dos cidadãos ${ }^{88}$. O prazo varia de acordo com o tópico e, de uma forma geral, o item mais antigo inicia em 11 de outubro de 2012 e o mais recente encerra em 15 de abril de 2014. Foram identificadas as seguintes temáticas: concorrên-

Comité das Regiões), com base nas funções que lhes são conferidas pelos Tratados; - através de contactos directos menos formalizados com as partes interessadas. No Livro Branco sobre Governança Europeia, a Comissão comprometeu-se a contribuir para uma cultura reforçada de consulta e diálogo na UE. [...] Os mecanismos de consulta são parte integrante das actividades de todas as instituições europeias, acompanhando todo o ciclo legislativo, desde a fase de concepção da política, que precede a proposta da Comissão, até à adopção final de uma medida pelo Parlamento e a respectiva implementação. Consoante o que esteja em jogo, pretende-se com as consultas proporcionar o contributo, designadamente, de representantes das autoridades regionais e locais, de organizações da sociedade civil, empresas e organizações de empresas, de cidadãos interessados, do meio académico e de técnicos especializados, bem como das partes interessadas de países terceiros (COMISSÃO, 2002a).

${ }^{87}$ Saliente-se que a análise do site foi realizada de forma sistemática, direta e não participativa durante o mês de janeiro de 2014.

${ }^{88}$ Informação acessada e conferida em 25 jan. 2014. 
cia (04 tópicos), transportes (03 tópicos), educação (01 tópico), energia (01 tópico), empresas (05 tópicos), saúde pública (01 tópico), mercado interno (01 tópico), ambiente (01 tópico), assuntos marítimos e pescas (02 tópicos), assuntos econômicos e financeiros (01 tópico) assuntos gerais e institucionais (01 tópico), fiscalidade (01 tópico) e consumidores (01 tópico) (A SUA VOZ, 2014c).

Neste item sobre os assuntos a serem consultados, bem como o prazo para tanto há a tradução em português. Entretanto, ao clicar sobre o ícone "Mais informações" que acompanha cada tópico para debate, as informações relacionadas à forma como se dará a consulta somente estão disponíveis apenas nas línguas oficiais da União Europeia, dentre as quais o português não está incluído.

No ícone "Mais informações" há, dentre outros, dados sobre o campo de atuação da proposta, quais são os grupos consultados, o período e objetivo da consulta, a forma de enviar a contribuição, razão do prazo da consulta, contatos, documentos e outros relacionados, inclusive outras consultas versando sobre temas conexos. Há a variação de tópicos de acordo com a temática envolvida e, no tópico "Educação", por exemplo, abre-se uma nova página da web em que para fazer a consulta é necessário abrir, após aquela, outra página em que há a consulta (EDUCATION, 2014).

Acerca da forma de envio das contribuições há duas variações: mediante o preenchimento de um formulário online, em que foram encontradas doze situações, bem como sob a forma de remessa via correio e/ou e-mail - localizados onze itens (A SUA VOZ, 2014c).

Além do mais, há a disponibilização de tabela com consultas programadas, ou seja, consultas a serem realizadas contendo, inclusive, a data estimada para a realização (A SUA VOZ, 2014d), bem como página com consultas já encerradas, as quais são divididas por ano e pelo tópico que foi discutido - da mesma forma que ocorre com as consultas em andamento -, contendo informações sobre o seguimento dado à discussão (A SUA VOZ, 2014e). Há, ainda, a disponibilização de verificação da consulta por domínio de intervenção, ou seja, por área de discussão, a exemplo: clima, assuntos aduaneiros, agenda digital, agricultura, ajuda ao desenvolvimento, ambiente, comércio, concorrência, consumidores, desporto, educação, emprego, energia, orçamento, pescas, redes de comunicações, segurança dos alimentos, tecnologias da informação, transportes, entre outros (A SUA VOZ, 2014f).

Quanto à segunda forma de participação - Debates - há a possiblidade de discussão sobre temas da atualidade em destaque, o compartilhamento e a troca de informações com outros cidadãos - é justamente esta última característica que tende a diferenciar os "Debates" das "Consultas", uma vez que nestas é possível, em tese, o estabelecimento de diálogo entre os cidadãos, ao passo que nas "Consultas" somente há a publicidade das manifestações dos cidadãos quando da publicação dos resultados da Consulta, porque enquanto a discussão está em curso não é possível verificar a opinião de outros cidadãos, mas apenas enviar comentários ao órgão responsável 
para compilação e organização das manifestações.

Porém, ao se analisar as formas de construção dos "Debates", verifica-se que não há interlocução entre os cidadãos. De acordo com o site, eles foram divididos em três formas: "Blogues", "Siga a UE nas redes sociais" e "Mais" (outras formas) (A SUA VOZ, 2014g). Ao clicar sobre o ícone "Blogues" há o redirecionamento à página da União Europeia com a listagem de Comissários e altos funcionários da Comissão Europeia e de outras instituições que detêm os próprios $b \operatorname{logs}$, a fim de que os cidadãos possam conhecer o ponto de vista destas pessoas em relação aos assuntos relacionados com a UE. São listados blogs da Comissão Europeia - Comissários -, em que abaixo do nome do Comissário há a temática tratada, a exemplo da Comissária Neelie Kroes, cujo assunto é a "Agenda digital"; de Representação da Comissão Europeia nos países da EU - há representantes dos seguintes países: Áustria, Bélgica, Estônia, Portugal, Espanha e Reino Unido; de Agência da União, qual seja, a Agência Europeia para Segurança e Saúde no Trabalho; bem como de um "Outro" - "Juvenes Translatores" (UNIÃO EUROPEIA, 2014c).

Quanto às redes sociais, abre-se uma lista de instituições, órgãos, agências, entre outros que possuem contas no Facebook que, clicando sobre o nome da entidade, há o redirecionamento à respectiva página do Facebook (UNIÃO EUROPEIA, 2014d). No que concerne às outras formas, também há o redirecionamento à página da União Europeia, com a possibilidade de ligar gratuitamente para um número (0080067891011); enviar perguntas por correio; contatar, visitar e consultar gabinetes da União na Europa e no resto do mundo; entabular perguntas a jornalistas e profissionais dos meios de comunicação; bem como contatar a equipe que gerencia o site (UNIÃO EUROPEIA, 2014e).

Por fim, o ícone "Outras ferramentas" é composto pelo contato aos deputados do Parlamento Europeu ou aos representantes do Comitê das Regiões dou Comitê Econômico e Social Europeu; pela possibilidade de inscrição como membro do painel de consulta de empresas, ou seja, um espaço para a emissão de opinião sobre questões relacionadas ao ambiente empresarial na Europa; comunicação de problemas encontrados nos serviços de informação e consulta - o espaço objetiva a reunião de oportunidade de negócio e emprego, formação e educação, viagens, direitos dos cidadãos, possibilidade de participação no processo de elaboração de políticas europeias, entre outros; verificar os resultados das sondagens de opinião; e, ainda, consulta ao Registro de Transparência para averiguar quais interesses gerais ou específicos influencia o processo de decisão nas instituições europeias - acesso a informações sobre os sujeitos envolvidos nas atividades, os interesses promovidos e os recursos investidos (A SUA VOZ, 2014h).

Em síntese esta é a estrutura do mecanismo que objetiva atrair a participação popular mediante informações claras e precisas sobre o trabalho que vem sendo desenvolvido, bem como que tem a pretensão de que os cidadãos possam emitir opiniões, de forma colaborativa e cooperativa, ao trabalho que vem sendo desenvolvido 
nesta organização supraestatal.

Entrementes, o que se percebe é a existência de vários mecanismos que tem por objetivo primordial a reunião de dados para o conhecimento dos cidadãos e não, como era esperado, espaços de deliberação, de interação e de contato entre os indivíduos. É um site que confere maior transparência aos processos decisórios da União Europeia sem, no entanto, permitir a construção de projetos, ideias e metas de forma coletiva. O ponto de maior inserção de opinião e de demonstração de interesses pelos cidadãos consiste no espaço destinado às Consultas. Porém da análise que foi realizada não foi possível verificar se as manifestações dos cidadãos são, efetivamente, empregadas e utilizadas para a tomada de decisão.

Outro ponto de admissão de diálogo foi encontrado em alguns blogs, verificando-se que, após a postagem dos Comissários, abria-se a possibilidade de inserção de comentários pelos cidadãos. Isto demonstra um dos elementos característico de tais espaços ${ }^{89}$, em que há a possibilidade de contato direto com o blogueiro ${ }^{90} \mathrm{e}$, principalmente, com outros leitores, com a finalidade de fazer análises, críticas e sugestões a respeito das informações veiculadas ou, até mesmo, inserir links para assuntos relacionados à temática da postagem.

Estes dois são os únicos espaços encontrados no site que se destacam ao chamarem a atenção dos cidadãos pela possibilidade de participação popular, de modo que haja influência na tomada de decisão, conduzindo a uma inteligência coletiva $^{91}$. É uma forma ainda incipiente de atração da população, pois detém espaços muito mais expositivos do que locais que permitam a concretização e efetivação de diálogo e/ou conversação entre as ordens e sujeitos dos variados níveis - cidadão, Estado, ordens transnacionais, União Europeia.

\section{Conclusão}

Aspirações por maior poder econômico e bélico, de um lado, e tentativas de conciliação de interesses e de construção de uma sociedade pacífica, de outro, sempre estiveram presentes no cenário global. Esta dualidade de posições revelou, ao longo do trabalho, grande interesse na proteção dos direitos humanos, que pode ocorrer através da construção de uma sociedade cosmopolita, adoção de uma repú-

\footnotetext{
${ }^{89}$ Segundo José Luis Orihuela (2007, p. 02) "Weblogs ou blogs são páginas pessoais da web que, à semelhança de diários on-line, tornam possível a todos publicar em rede. Por ser a publicação on-line centralizada no usuário e nos conteúdos, e não na programação ou no design gráfico, os blogs multiplicaram o leque de opções dos internautas de levar para a rede conteúdos próprios sem intermediários, atualizados e de grande visibilidade para os pesquisadores". ${ }^{90}$ Blogueiro é o termo designado para se referir ao dono do blog, ou a pessoa que edita o conteúdo disponibilizado na página, bem como as pessoas que postam frequentemente em páginas pessoais da web (RODRIGUES, 2014, p. 4).

${ }^{91}$ É conhecida como a inteligência que está em toda a parte e, em tempo real, é recriada por várias pessoas que concentram algum tipo de saber (LÉVY, 1999, p. 28).
} 
blica mundial federal complementar e subsidiária ou, então, por meio da conversação entre Estados e ordens transnacionais.

Atualmente, uma das formas encontradas que detêm maior atuação e efetividade para solucionar os problemas jurídico-políticos que atingem os Estados, organizações e ordens normativas transnacionais (como a lex mercatoria, lex sportiva e lex digitalis) é justamente a "conversação" transconstitucional. Esta forma de diálogo vem sendo de grande importância ao reconhecer a autonomia e a importância de outros atores internacionais, que não apenas os Estados. Revela-se como um mecanismo que prima pela regulação e, consequentemente, solução de conflitos emergentes em nível global.

Além do mais, no âmbito da União Europeia, verifica-se a existência da "margem de apreciação" dos Estados, reconhecendo as peculiaridades de traços culturais e religiosos no âmbito das decisões judiciais. São modos não complexos aptos a encontrar soluções pacíficas e coerentes ao litígio em questão que não dizem respeito ao aspecto homogêneo e dominador da globalização. Por isso, demonstram estar em crescente atuação e utilização, uma vez que são capazes de conciliar os mais diversos interesses.

Também não se deve perder de vista o protagonismo dos cidadãos. Estes devem ser considerados não como um fim em si mesmo, mas como um meio e um objetivo a ser alcançado. Atualmente, com as facilidades trazidas por novas formas de comunicação online, a exemplo da Internet, há a possibilidade de reunião dos cidadãos para, mediante a construção de debates e ideias coletivas, influenciarem na tomada de decisão sobre questões que lhes dizem respeito.

Os governos dos mais variados níveis devem buscar a integração e aproximação com os cidadãos, o que pode ser percebido através da experiência online que vem sendo desenvolvida na União Europeia, conhecida como "A sua voz na Europa". É uma iniciativa ainda pioneira e em construção e que objetiva atrair o indivíduo para perto da União, demonstrando, na prática, a possibilidade de existência de uma solidariedade entre os povos - e, quem sabe, a constituição de um povo constitucional europeu ou de uma identidade europeia -, pois as discussões travadas neste espaço não dizem respeito a um único Estado, mas a um todo constituído por vários Estados.

Entretanto, dentre as características analisadas, verifica-se que apesar de se revelar um mecanismo de potencial aproximação entre os cidadãos e destes com a União, ainda não mostrou um cenário promissor e atraente. Funciona como um local para a publicidade, divulgação e reunião de informações, não se vislumbrando - exceto nos blogs e nas Consultas - a possibilidade de interlocução entre as partes, ou seja, de conversação entre os próprios cidadãos e nem destes com a União.

Apesar de sua relevância, ainda precisa de aperfeiçoamento e maior dedicação dos Estados e organismos supraestatais e internacionais com a finalidade de criar formas em que haja verdadeira participação e deliberação por parte dos cida- 
dãos. É necessário, neste mundo conectado e globalizado, que não se perca de vista o principal objetivo: a construção de sistemas de proteção aos direitos humanos e, para tanto, ninguém melhor do que o próprio indivíduo para manifestar as suas preferências e interesses neste processo de construção cooperativa, global e colaborativa.

\section{REFERÊNCIAS}

A SUA VOZ NA EUROPA. Informações sobre este sítio Web. Disponível em: http://ec.europa.eu/yourvoice/about/index_pt.htm\#background. Acessado em: 22.01.2014a.

Página inicial. Disponível em: http://ec.europa.eu/yourvoice/index pt.htm. Acessado em: 22.01.2014b.

Consultas em curso. Disponível em: http://ec.europa.eu/yourvoice/ consultations/index_pt.htm. Acessado em: 22.01.2014c.

Planned Public Consultations. Disponível em: http://ec.europa. eu/yourvoice/consultations/docs/planned-consultations_en.pdf. Acessado em: 22.01.2014d.

Consultas encerradas. Disponível em: http://ec.europa.eu/yourvoice/ consultations/2013/index_pt.htm. Acessado em: 22.01.2014e.

. Consultas por domínio de intervenção. Disponível em: http://ec.europa.eu/yourvoice/consultations/links/index_pt.htm. Acessado em: 22.01.2014f.

. Debates. Disponível em: http://ec.europa.eu/yourvoice/discussions/ index_pt.htm. Acessado em: 23.01.2014g.

. Outras ferramentas. Disponível em: http://ec.europa.eu/yourvoice/ usefullinks/index_pt.htm. Acessado em: 23.01.2014h.

CASTELLS, Manuel. Redes de indignação e esperança: movimentos sociais na era da internet. Tradução Carlos Alberto Medeiros. 1 ed. Rio de Janeiro: Zahar, 2013.

COMISSÃO DAS COMUNIDADES EUROPEIAS. Comunicação da Comissão: para uma cultura reforçada de consulta e diálogo - Princípios gerais e regras mínimas de consultas de partes interessadas pela Comissão. Bruxelas, 11 dez. 2002a. Disponível em: http://eur-lex.europa.eu/LexUriServ/LexUriServ.do?uri=COM:2002:0704:FIN:PT:PDF. Acessado em: 22.01.2014.

. Comunicado da Comissão: Governança Europeia: Legislar Melhor. Bruxelas, 05 jun. 2002b. Disponível em: http://eur-lex.europa.eu/LexUriServ/LexUriServ.do?uri=COM:2002:0275:FIN:PT:PDF. Acessado em: 22.01.2014.

DELMAS-MARTY, Mireille. Três desafios para um Direito Mundial. Tradução e posfácio Fauzi Hassan Choukr. Rio de Janeiro: Lumen Juris, 2003. 
Résister, responsabiliser, anteciper. Paris: Seiul, 2013.

EDUCATION \& CULTURE. Consultations. Disponível em: http://ec.europa. eu/dgs/education_culture/more_info/consultations/index_en.htm. Acessado em: 22.01.2014.

HABERMAS, Jürgen. A constelação pós-nacional: ensaios políticos. Tradução Márcio Seligmann-Silva. São Paulo: Littera Mundi, 2001.

HELD, David. La democracia y el orden global: del Estado moderno al gobierno cosmopolita. Barcelona: Paidós, 1997.

HÖFFE, Otfried. Derecho Intercultural. Barcelona: Gedisa Editorial, 2000. . A democracia no mundo de hoje. São Paulo: Martins Fontes, 2005.

JULIOS-CAMPUZANO, Afonso. Pluralismo jurídico e constituição na ordem global. In: MORAIS, José Luis Bolzan; COPPETI NETO, Alfredo (Org.). Estado e constituição: a internacionalização do direito a partir dos direitos humanos. Ijuí: Unijuí, 2013.

KANT, Immanuel. À paz perpétua. Trad. Marco Zingano. Porto Alegre: L\&PM, 2010.

LÉVY, Pierre. Ciberdemocracia. Lisboa: Instituto Piaget, 2003.

. A inteligência coletiva: por uma antropologia do ciberespaço. 2. Ed. Tradução de Luiz Paulo Rouanet. São Paulo: Loyola, 1999.

MARGEN DE APRECIACIÓN. Tribunal Europeo de Derechos Humanos. Disponível em: https://www.scjn.gob.mx/Transparencia/Lists/Becarios/Attachments/165/ Becarios_163.pdf. Acessado em: 21.01.2014.

MOLES, John L. Cosmopolitismo cínico. In: GOULET-CAZÉ, Marie-Odile; BRANHAM, R. Bracht. Os cínicos: o movimento cínico na Antiguidade e seu legado. Tradução Cecília Camargo Bartalotti. São Paulo: Edições Loyola, 2007.

MORAIS, José Luis Bolzan de; SALDANHA, Jânia Maria Lopes; VIEIRA, Gustavo Oliveira. O constitucionalismo e a internacionalização dos direitos humanos. In: MORAIS, José Luis Bolzan; COPPETI NETO, Alfredo (Org.). Estado e constituição: a internacionalização do direito a partir dos direitos humanos. Ijuí: Unijuí, 2013.

NEVES, Marcelo. Transconstitucionalismo. São Paulo: Martins Fontes, 2009.

ORIHUELA, José Luis. Blogs e blogosfera: o meio e a comunidade. In: ORDUÑA, Octavio I. Rojas... (et al.). BLOGS: revolucionando os meios de comunicação. São Paulo: Thomson Learning, 2007.

RODRIGUES, Catarina. Blogs: uma ágora na net. Disponível em: http://www.labcom.ubi.pt/files/agoranet/04/rodrigues-catarina-blogs-agora-na-net.pdf. Acessado 
em: 24.01.2014.

SANTOS, Boaventura de Sousa. Os processos da globalização. In SANTOS, Boaventura de Sousa (org). A Globalização e as Ciências Sociais. 3. ed. São Paulo: Cortez, 2011.

SLAUGHTER, Anne-Marie; BURKE-WHITE, William. The Future of International Law Is Domestic (or, The European Way of Law). In: Harvard International Law Journal. Volume 47, Number 2, Summer 2006. Disponível em: https://www.law. upenn.edu/cf/faculty/wburkewh/workingpapers/47HarvIntlLJ327(2006).pdf. Acessado em: 25.01.2014.

TRIBUNAL EUROPEU DE DIREITOS HUMANOS. Convenção Europeia de Direitos do Homem: com as modificações introduzidas pelos Protocolos nos 11 e 14 acompanhada do Protocolo adicional e dos Protocolos nos 4, 6, 7, 12 e 13. Conselho da Europa, 1950. Disponível em: http:/www.echr.coe.int/Documents/Convention_ POR.pdf. Acessado em: 20.01.2014.

UNIÃO EUROPEIA. Os países da União Europeia. Disponível em: http://europa. eu/about-eu/countries/member-countries/index_pt.htm. Acessado em: 20.01.2014a.

. Informações de base sobre a União Europeia. Disponível em: http:// europa.eu/about-eu/index_pt.htm. Acessado em: 20.01.2014b.

. Blogues. Disponível em: http://europa.eu/contact/take-part/blogs/index_pt.htm. Acessado em: 23.01.2014c.

. Contas no Facebook. Disponível em: http://europa.eu/contact/take -part/facebook/index_pt.htm\#2. Acesso em: 23.01.2014d.

- Contactar a UE. Disponível em: http://europa.eu/contact/index_ pt.htm. Acessado em: 23.01.2014e.

ZAGREBELSKY, Gustavo. El derecho dúctil. Ley, derechos e justicia. 5. ed. Madrid: Editorial Trotta, 2007.

ZOLO, Danilo. La prospettiva del governo mondiale. Milão: Feltrinelli, 2008. 